\title{
Pengaruh Media Animasi pada Pembelajaran Suhu dan Kalor terhadap Hasil Belajar IPA Kelas V SD Negeri 14 Waigama
}

\author{
Endah Pebriani Rahman, Asrul, Fathurrahman \& Indri Anugrah Ramadhani \\ Universitas Pendidikan Muhammadiyah Sorong \\ Email: endah.febriani.rahman@gmail.com
}

\begin{abstract}
Abstrak: Penelitian ini bertujuan untuk melihat pengaruh terhadap hasil belajar siswa pada mata pelajaran IPA di kelas V di SD Negeri 14 Waigama Misool Utara, Berbantuan media animasi. Jenis penelitian yang dilakukan yaitu penelitian eksperimen. Instrumen yang digunakan adalah lembar observasi guru dan siswa, lembar penilaian kerja kelompok serta lembar tes tertulis dalam bentuk pilihan ganda. Data yang diperoleh melalui analisis secara deskriptif dengan mengacu pada ketuntasan belajar klasikal. Data menunjukkan rata-rata skor observasi guru (peneliti) dan siswa sebesar 100\% dengan kriteria sangat baik. Hasil analisis ketuntasan belajar pada nilai rata - rata pretest $38,75 \%$, rata - rata posttest $71 \%$, hasil uji reliabilitas diperoleh Cronbach"s Alpha untuk instrument test sebesar 0,704 yang berarti memiliki reliabilitas baik. Uji normalitas hasil belajar pretest siswa kelas $\mathrm{V}$ memiliki taraf signifikansi 0,259 >0,05 sedangkan hasil belajar postest siswa kelas $\mathrm{V}$ memiliki taraf signifikansi 0,906 >0,05. Uji hipotesis diperoleh $\mathrm{t}_{\text {hitung }}$ sebesar 2.204 dengan $\mathrm{dk}=\mathrm{n}-1$ (20$1=19)$ diperoleh $t_{\text {tabel }}$ sebesar 1.729. Berdasarkan hasil analisi data nilai yaitu $t_{\text {hitung }}>t_{\text {tabel }}$ (2.204 > 1.729), dengan besarnya taraf signifikansi 0,05, yakni $(0,040<0,05)$ maka Hipotesis diterima, Dengan demikian dapat disimpulkan bahwa terdapat pengaruh penggunaan media animasi pada pembelajaran suhu dan kalor terhadap hasil belajar kognitif IPA siswa kelas V SD Negeri 14 Waigama Misool Utara.
\end{abstract}

Kata kunci: Hasil Belajar IPA, Media Animasi, Suhu dan Kalor,

Abstract: The purpose of this reseach is to find out The effect of animation media on temperature and heat learning on the science cognitive learning outcomes in grade $V$ elementary school 14 waigama, North Misool by using animation media. This research conducted by using experimental research. Instruments of this research are teacher and student obsevation sheet, group work assessment sheets and written test sheets in the form of muktiole choice. Data obtained through descriptive analysis withbreference to classical learning completeness. Data shows that the average score of observation of teacher (researcher) and students by $100 \%$ with exellent criteria. The result analysis of learning completeness at the pre test average value amounting to $38.75 \%$., posttest average balue amounting to $71 \%$. The reliability test result obtained by cronchbach' Alpha for the test instrument is 0.794 which means it has a goig reliability value. Normality test of pre test learning outcomes of fifth grade students has a significance level if 0.259>0.005. Hypothesis testing obtained $t$ count 2.204 with $d k=n-1$ (20-1=19) obtained t table of 1.729. Based on the result of data analysis value that that $t$ count $>t$ table $(2.204>1.278)$ with a significance level of 0.05 is (0.040<0.005), the hypothesis is accepted that it can be conluded that there is an effect of the use animation media on the learning temoerature and heat on the science cognitive learning outcomes in grade V elementary school 14 waigama, North Misool.

Keywords: animation media, science lerning outcomes, temperature and heat, 


\section{Pendahuluan}

Pendidikan dapat mengembangkan potensi yang ada pada diri manusia, baik potensi jasmani maupun rohani. Begitu pentingnya pendidikan, sejalan dengan pemikiran yang berada dalam pembukaan UUD 1945 disebutkan bahwa salah satu tujuan negara adalah mencerdaskan kehidupan bangsa. UU RI NO. 20 tahun 2003 tentang SISDIKNAS yaitu :"Terwujudnya sistem pendidikan sebagai pranata sosial yang kuat dan berwibawa untuk memberdayakan semua warga Negara Indonesia berkembang menjadi manusia yang berkualitas sehingga mampu dan proaktif menjawab tantangan zaman yang selalu berubah"(Munirah, 2015: 234).

Melalui pendidikan nasional setiap bangsa merancang strategi pengembangan sumber daya manusia yang mempunyai seperangkat karakter dan kompetensi untuk berperan aktif dalam perwujudan tatanan sosial yang adil dan beradab. Sistem pendidikan nasional pada hakikatnya merupakan pencerminan dari upaya sadar sebuah bangsa untuk membangun keberlanjutan warisan budaya dan jati diri sebagai bangsa berdaulat dan bermartabat (Musanna, 2017:118). Berdasarkan uraian tersebut menunjukkan betapa pentingnya suatu pendidikan, melalui pendidikan yang berkualitas akan menciptakan sumber daya manusia yang berkualitas pula.

Mata Pelajaran Ilmu Pengetahuan Alam (IPA) penting dipelajari oleh siswa Sekolah Dasar karena IPA berhubungan dengan cara mencari tahu tentang alam secara sistematis, sehingga IPA bukan sekedar penguasaan kumpulan pengetahuan yang berupa fakta-fakta, konsep-konsep, atau prinsip-prinsip saja melainkan juga merupakan suatu proses penemuan. Perlunya pembelajaran IPA yang langsung bersentuhan dengan proses mental siswa seperti pendapat lain yang mengatakan bahwa Pelajaran menarik dan berhasil apabila dikaitkan dengan lingkungan sekitar siswa dimana mereka dapat mencari, mencoba, berpikir dan menemukan solusi terhadap permasalahan yang dihadapi (Asrul, 2018:49). Pendidikan IPA diharapkan dapat menjadi tempat bagi peserta didik untuk mempelajari diri sendiri dan alam sekitar, serta prospek pengembangan lebih lanjut dalam menerapkannya di dalam kehidupan sehari-hari.

Berdasarkan observasi yang telah dilakukan disekolah, dimana kondisi di dalam kelas begitu pasif, kebanyakan dari siswa hanya mengobrol atau memilih bermain dengan teman sebangkunya dibandingkan memperhatikan materi yang diajarkan. Selain siswa, peneliti melihat guru sekedar mengajar terfokus pada buku paket yang ada, dengan metode ceramah dan tanya jawab yang digunakan tidak adanya variasi dalam cara mengajarnya, tanpa tahu apakah cara yang diajarkan sudah sesuai dan dipahami oleh siswanya atau sebaliknya. Keadaan tersebut membuat proses pembelajaran menjadi tidak efektif, metode yang diterapkan guru tidak sesuai dengan mata pelajaran IPA yang berakibat pada hasil belajar siswa menjadi rendah.

Dalam hasil wawancara kepada wali kelas V yang dilakukan oleh peneliti diperoleh, bahwa hasil tes siswa rata-rata pada mata pelajaran IPA dibawah dari KKM (70). Rendahnya hasil belajar diakibatkan kurangnya variasi dalam mengajar, ceramah dan tanya jawab menjadi makanan sehari-hari yang diberikan oleh guru pada siswanya. Jika hasil belajar yang diperoleh memenuhi standar, hasil tersebut menunjukkan berhasilnya seorang guru dalam penyampaian materi dalam proses pembelajaran. Oleh sebab itu alangkah baiknya jika guru menggunakan media pembelajaran yang menarik perhatian siswa, sehingga mereka lebih termotivasi dan semangat dalam memperoleh pelajaran. 
Dalam penelitian ini peneliti ingin menggunakan media pembelajaran animasi untuk pembelajaran IPA khususnya pada materi suhu dan kalor. Sesuai dengan latar belakang tersebut, peneliti tertarik untuk melakukan penelitian, tujuan penelitian ini adalah untuk mengetahui pengaruh media animasi pada pembelajaran suhu dan kalor terhadap hasil belajar kognitif IPA kelas V SD Negeri 14 Waigama Misool Utara.

Manfaat penelitian adalah sebagai bahan untuk memperoleh gambaran mengenai pengaruh media pembelajaran pada hasil belajar kognitif IPA serta hasil dari penelitian ini dapat menambah ilmu pengetahuan serta wawasan terkait dengan masalah pada penelitian ini di masa yang akan datang.

\section{Metode Penelitian}

Jenis penelitian yang digunakan peneliti yaitu penelitian pre-eksperimen. Alasan peneliti menggunakan penelitian pre-eksperimen karena peneliti ingin melihat pengaruh dari suatu perlakuan yaitu penggunaan media animasi terhadap sampel tertentu menggunakan kelompok eksperimen yaitu siswa kelas V, tanpa kelompok kontrol.

Desain yang digunakan dalam penelitian ini adalah one group Pretest-Posttest design karena peneliti ingin melihat pengaruh perlakuan pada sampel menggunakan hasil pretes dan posttest. Dalam penelitian ini peneliti memberikan pretest sebelum perlakuan dan posttest setelah diberi perlakuan. Hasil perlakuan dapat dilihat dengan keadaan sebelum diberi perlakuan. Sugiono (2016:74) menggambarkan one group pretest-Posttest design sebagai berikut :

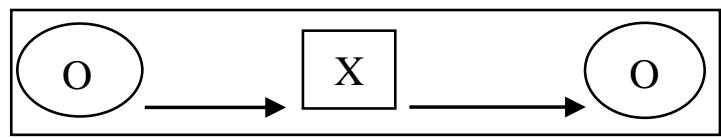

Gambar 1. Desain Penelitian

Keterangan :

$\mathrm{O}_{1}=$ Nilai pretest (sebelum perlakuan)

$\mathrm{O}_{2}=$ Nilai postest (setelah diberi perlakuan)

$\mathrm{X}=$ Perlakuan

Definisi operasional pada penelitian ini adalah : hasil belajar IPA pada pembelajaran suhu dan kalor yakni : tercapainya tujuan pembelajaran suhu dan kalor oleh siswa berdasarkan standar kompetensi dan kompetensi dasar. Hasil belajar IPA pada pembelajaran suhu dan kalor dalam penelitian ini adalah siswa mampu mengetahui benda-benda sekitar yang dapat menghantarkan panas, siswa dapat membedakan suhu dan kalor dan mampu mengidentifikasi berbagai jenis perpindahan kalor dalam kehidupan sehari-hari. Media Animasi : media adalah suatu benda yang digunakan untuk menyampaikan pesan yang oleh sumber pesan ingin diteruskan kepada penerima pesan, bahwa pesan yang ingin disampaikan berupa materi pelajaran, sehingga mampu merangsang minat siswa dan proses belajarpun terjalin dengan terarah. Media animasi dalam peelitian ini digunakan agar siswa lebih mudah memahami materi suhu dan kalor.

Dalam penelitian ini yang menjadi variabel bebasnya yaitu media animasi dan yang menjadi variabel terikat yaitu hasil belajar Kognitif IPA siswa. Penelitian dilaksanaan di kelas 
V SD Negeri 14 Waigama Misool Utara, kabupaten Raja Ampat. Adapun yang menjadi populasi dalam penelitian ini adalah seluruh siswa SD Negeri 14 Waigama Misool Utara, tahun ajaran 2018-2019 yang berjumlah 148 siswa. Dengan menggunakan penarikan sampel Non Probability Sampling dengan teknik purposive yaitu metode penentuan sampel dengan pertimbangan tertentu. Peneliti melakukan pertimbangan pengambilan sampel dengan penelitian pada materi suhu dan kalor dan materi tersebut berada di kelas V. Dalam penelitian ini sampel yang diambil adalah seluruh siswa kelas V SD Negeri 14 Waigama Misool Utara yang berjumlah 20 siswa.

Teknik pengumpulan data yang digunakan dalam penelitian ini antara lain tes, observasi dan dokumentasi. Tes yang diberikan dalam penelitian ini berupa tes tulis dengan bentuk soal pilihan ganda terdiri dari 20 soal, mencakup materi suhu dan kalor pada pembelajaran IPA. observasi ini digunakan untuk mengamati proses pembelajaran didalam kelas khususnya pada pembelajaran IPA pada kelas V SD Negeri 14 Waigama Misool Utara Tahun Ajaran 2018/2019. Observasi dilakukan dengan menggunakan lembar observasi aktivitas guru dan siswa selama dalam mengajar dengan menggunakan media pembelajaran animasi dalam proses pembelajaran. dokumentasi yaitu berupa foto-foto, buku-buku yang relevan dan laporan kegiatan selama penelitian. Instrumen ini digunakan untuk mengetahui daftar nama siswa dan daftar guru, foto pelaksanaan selama penelitian dan hasil pekerjaan siswa selama pembelajaran.

Validasi isi oleh ahli uji dilakukan untuk mengambil keputusan dengan mengirimkan panduan lembar validasi kepada validator. Hasil dari lembar validasi yang berisi pertanyaan tentang isi, struktur, dan evaluasi dijadikan masukan dalam memperbaiki dan mengembangkan instrumen. Pada penelitian ini peneliti menggunakan 2 Expert Judgement (uji ahli) yaitu dosen IPA sebagai ahli dalam media dan materi. Kemudia Untuk mencari koefisien reliabilitas instrumen tes, peneliti menggunakan rumus K-R.20 yang diketemukan oleh Kuder dan Richadson (Siregar, 2017: 74) sebagai berikut :

Keterangan:

$$
r_{11}=\left(\frac{k}{k-1}\right)\left(\frac{v_{t}-\Sigma p q}{V_{t}}\right)
$$

$\mathrm{r}_{11}=$ Reliabilitas instrumen

$\mathrm{k}=$ Jumlah butir pertanyaan

$V_{t}=$ Varians total

$\mathrm{p}=$ Proporsi banyaknya subjek yang menjawab benar

$\mathrm{q}=$ Proporsi banyaknya subjek yang menjawab salah

Kriteria pengujian, jika nilai reliabilitas instrument $r_{11}>0,7$ maka intrumen penelitian dinyatakan reliabel (Siregar, 2017: 73). Dalam penelitian ini untuk menganalisis data menggunakan analisis deskriptif kuantitatif. Pada penelitian ini dilakukan uji prsayarat yaitu uji normalitas yang menggunakan Uji Kolmogrov-Smirnov untuk mengetahui persebaran data yang dilakukan normal atau tidak. Penelitian ini dalam mengkategorikan subjek yang memiliki hasil belajar cenderung tinggi dan rendah dengan menggunakan uji hipotesis satu sampel (one sample t test). 


\section{Hasil dan Pembahasan}

Peneliti menguji validitas instrument tes yang digunakan sebagai instrumen penelitian untuk menentukan bahwa instrument tes tersebut layak diberikan kepada sampel. Sampel yang diteliti yaitu kelas V yang terdiri dari 20 siswa sebagai kelas eksperimen. Setelah Instrumen tersebut dinyatakan valid maka langkah selanjutnya yang dilakukan yaitu mencari reliabilitas suatu data hasil belajar siswa, Untuk menguji reliabilitas instrument peneliti melakukannya melalui hasil uji coba soal pada sample yang berbeda. Berdasarkan perhitungan uji reliabilitas terhadap instrumen tes menggunakan Kuder dan Richardson (K-R 20), diperoleh hasil nilai reliabilitas $\left(r_{11}\right)$ untuk instrument test sebesar 0,704. Berdasarkan kriteria pengujian, jika nilai reliabilitas instrument $\left(r_{11}\right)>0,7$ maka instrument penelitian reliabel. Dengan demikan, instrument tersebut telah memenuhi syarat reliabel.

Metode tes digunakan peneliti untuk mengetahui hasil belajar IPA siswa. Tes yang digunakan terdiri dari dua puluh soal pilihan ganda tentang suhu dan kalor. Tabel 1 menunjukkan bahwa banyaknya kelas ada 6 dengan panjang tiap interval kelas adalah 6 . Nilai yang paling banyak diperoleh siswa terletak pada interval 34 - 40 yaitu sebesar $40 \%$ (8 orang dari 20 siswa). Sedangkan nilai yang paling sedikit diperoleh terletak pada interval 48 - 54 yaitu sebesar 5\% (1 orang dari 20 siswa). Nilai rata-rata diperoleh untuk nilai pretes ini adalah 38,75 .

Tabel 1. Distribusi Hasil Belajar Pretest Siswa

\begin{tabular}{lcc}
\hline Nilai & Frekuensi & Relatif\% \\
\hline $20-26$ & 3 & 15 \\
$27-33$ & 2 & 10 \\
$34-40$ & 8 & 40 \\
$41-47$ & 2 & 10 \\
$48-54$ & 1 & 5 \\
$55-61$ & 4 & 20 \\
Jumlah & $\mathbf{2 0}$ & $\mathbf{1 0 0} \%$ \\
\hline
\end{tabular}

Nilai postes ditunjukkan bahwa banyaknya kelas ada 6 dengan panjang tiap interval kelas adalah 10. Nilai yang paling banyak diperoleh siswa terletak pada interval 62 - 72 dan 73-83 yaitu sebesar 30\% (6 orang dari 20 siswa). Sedangkan nilai yang paling sedikit diperoleh terletak pada interval 40-50 dan 95-105 yaitu sebesar 5\% (1 orang dari 20 siswa). Nilai rata-rata diperoleh unuk nilai pretes ini adalah 71.

Tabel 2. Distribusi Hasil Belajar Postes Siswa

\begin{tabular}{lcc}
\hline Nilai & \multicolumn{2}{c}{ Frekuensi } \\
& Absolut & Relatif \% \\
\hline $40-50$ & 1 & 5 \\
$51-61$ & 4 & 20 \\
$62-72$ & 6 & 30 \\
$73-83$ & 6 & 30 \\
$84-94$ & 2 & 10 \\
$95-105$ & 1 & 5 \\
Jumlah & $\mathbf{2 0}$ & $\mathbf{1 0 0} \%$ \\
\hline
\end{tabular}


Sebelum analisa data dilakukan ada tahapan yang harus dilalui yakni data terlebih dahulu harus di uji apakah memenuhi prasyarat uji statistik One Sample t-Test. Analisis yang digunakan adalah analisis statistik inferensial. Untuk melakukan analisis statistik inferensial dalam menguji hipotesis, maka diperlukan pengujian dasar terlebih dahulu meliputi uji normalitas. Berdasarkan Tabel 3, yang diperoleh perhitungan dengan menggunakan SPSS versi 16 hasil belajar pretest siswa kelas $\mathrm{V}$ memiliki taraf signifikansi 0,259>0,05 sedangkan hasil belajar postest siswa kelas $\mathrm{V}$ memiliki taraf signifikansi 0,906 $>0,05$ sehingga dapat disimpulkan bahwa kelas V sebagai kelas eksperimen berdistribusi normal. Dapat disimpulkan bahwa data dalam penelitian memiliki varian yang sama, dan data layak digunakan untuk uji selanjutnya, yaitu uji hipotesis.

Tabel 3. Uji Normalitas Kolmogorov-smirnov Kelas Ekperimen

\begin{tabular}{lccc}
\hline Jenis Tes & Asymp. Sig & $\boldsymbol{A}$ & Keterangan \\
\hline Pretest & 0,259 & 0,05 & $0,259>0,05$ Normal \\
Posttest & 0,906 & 0,05 & $0,906>0,05$ Normal \\
\hline
\end{tabular}

Pada pengujian hipotesis pada Tabel 4, dengan menggunakan uji -one sample t test karena terdapat satu varian dimana data yang diuji yaitu hasil posttest dari kelas eksperimen berdasarkan hasil perhitungan maka diperoleh $t_{\text {hitung }}$ sebesar 2.204 dengan $\mathrm{dk}=\mathrm{n}-1$ (20$1=19)$ diperoleh $t_{\text {tabel }}$ sebesar 1.729. Berdasarkan hasil analisi data nilai yaitu $t_{\text {hitung }}>t_{\text {tabel }}$ (2.204> 1.729), dengan besarnya taraf signifikansi 0,05 , yakni $(0,040<0,05)$ maka Hipotesis diterima, berarti dapat disimpulkan bahwa terdapat perbedaan yang signifikan rata- rata hasil belajar siswa dengan media pembelajaran animasi IPA dengan siswa yang diajar dengan metode ceramah yang artinya ada pengaruh pembelajaran dengan media animasi terhadap hasil belajar IPA kelas V SD Negeri 14 Waigama Misool Utara pada Tahun Ajaran 2019/2020.

\begin{tabular}{lccc}
\multicolumn{4}{c}{ Tabel 4. Uji T } \\
\hline tailed) & $\boldsymbol{T}$ & $\boldsymbol{d} \boldsymbol{f}$ & Sig. $(\mathbf{2}$ \\
\hline Posttest & 2.204 & 19 & .040 \\
\hline
\end{tabular}

\section{Kesimpulan}

Terdapat pengaruh antara media animasi pada pembelajaran suhu dan kalor terhadap hasil belajar kognitif IPA kelas V SD Negeri 14 Waigama Misool Utara”. Uji hipotesis peneliti menggunakan uji -t test one sample test dimana data yang diuji yaitu hasil posttest dari kelas eksperimen berdasarkan hasil perhitungan maka diperoleh $\mathrm{t}_{\text {hitung }}$ sebesar 2.204 dengan $\mathrm{dk}$ $=\mathrm{n}-1(20-1=19)$ diperoleh $\mathrm{t}_{\text {tabel }}$ sebesar 1.729. Berdasarkan hasil analisis data nilai yaitu $t_{\text {hitung }}>t_{\text {tabel }}(2.204>1.729)$, dengan besarnya taraf signifikansi 0,05 yakni $(0,040<0,05)$ maka hipoteis diterima, serta hasil penelitian yang didasarkan pada analisis data dan pengujian hipotesis, maka kesimpulan yang dapat dikemukakan dalam penelitian ini yaitu terdapat pengaruh yang signifikan pada penggunaan media animasi terhadap hasil belajar kognitif IPA siswa kelas V SD Negeri 14 Waigama Misool Utara pada tahun ajaran 2019/2020. 
Keterbatasan dalam penelitian ini adalah lokasi sekolah yang jauh dari perkotaan, kemudian penggunaan infocus sebagai sarana untuk menggunakan media animasi masih terbatas.

\section{Daftar Pustaka}

Asrul, A., Ridlo, S., \& Susilo, S. (2018). Creative Thinking Analysis, Motivation and Concept Mastery on Learning of Cooperative Discovery Model in Elementary School. Journal of Primary Education, 7(1), 48-56.

Ayuningdyah, M., \& Khotimah, K. (2018) "Pengembangan Media Animasi Pelajaran Matematika Materi Bidang Datar Simetris Untuk Siswa Kelas IV di SDN Jatikalen 3 Nganjuk", Jurnal Teknologi Pendidikan, I. hal. 1-5.

Busyaeri, A., Udin, T., \& Zaenuddin, A. (2016) "Pengaruh Penggunaan Video Pembelajaran Terhadap Peningkatan Hasil Belajar Mapel IPA di Min Kroya Cirebon",Al Ibtida, I, hal. 116-137.

Dewi, B. S., Kristiantari, M. G. R., \& Negara, O. (2014) "Model Tematik Bernuansa Kearifan Lokal Berbantuan Media Animasi Berpengaruh Terhadap Hasil Belajar IPA Siswa Kelas III SD Negeri Gugus Kapten Japa",Mimbar PGSD Universitas Pendidikan Ganesha, hal. 1-10.

Elpira, N., \& Ghufron, A. (2015)"Pengaruh Penggunaan Media Pewerpoint Terhadap Minat dan Hasil Belajar IPA Siswa Kelas IV SD",Jurnal Inovasi Teknologi Pendidikan, I, hal. 94-104.

Karitas, D.,Fransiska. Panas dan Perpindahannya. Jakarta: Kementrian Pendidikan dan Kebudayaan, 2017.

Munirah. (2015) "Sistem Pendidikan di Indonesia: Antara Keinginan dan Realita", Auladuna, II , hal. 233-245.

Musanna, A. (2017), "Indigenisasi Pendidikan: Rasionalitas Revitalisasi Praksis Pendidikan Ki Hadjar Dewantara", Pendidikan Dan Kebudayaan, I. hal. 117-133.

Nurhikmah, B. E., Antara, A. P., \& Magta, M. (2017) "Pengaruh Metode Bercakap-Cakap Melalui Media Animasi Terhadap Kemampuan Membaca Permulaan Anak Kelompok B",e-Journal Pendidikan Anak Usia Dini Universitas Pendidikan Ganesha, II hal. 1-10.

Rahayuningsih, N., Ashadi, \& Sarwanto. (2013), "Pembelajaran Biologi Dengan Model CLT (Contextual Teaching and Learning) Menggunakan Media Animasi dan Media Lingkungan Ditinjau Dari Sikap Ilmiah dan Gaya Belajar",Jurnal Inkuiri, II hal. 173183.

Sembiring, E. B. (2015), "Pengembangan Media Sosialisasi Etika Kampus Dalam Bentuk Animasi 2D", Teknomatika, II, hal. 13-26.

Siregar, Syofyan. 2017. Metode Penelitian Kuantitatif dilengkapi dengan Perbandingan 
Perhitungan Manual \& SPSS. Jakarta: Kencana,.

Sugiono. 2009. Metode Penelitian Kuantitatif, Kualitatif dan R\&D. Bandung: Alfabeta,.

Syofyan, H. (2015) "Peningkatan Hasil Belajar IPA Siswa Kelas V Melalui Metode Resitasi di SD Al Azhar Syifa Budi Jakarta Selatan", Jurnal Pendidikan Dasar, I hal. 134-150. 